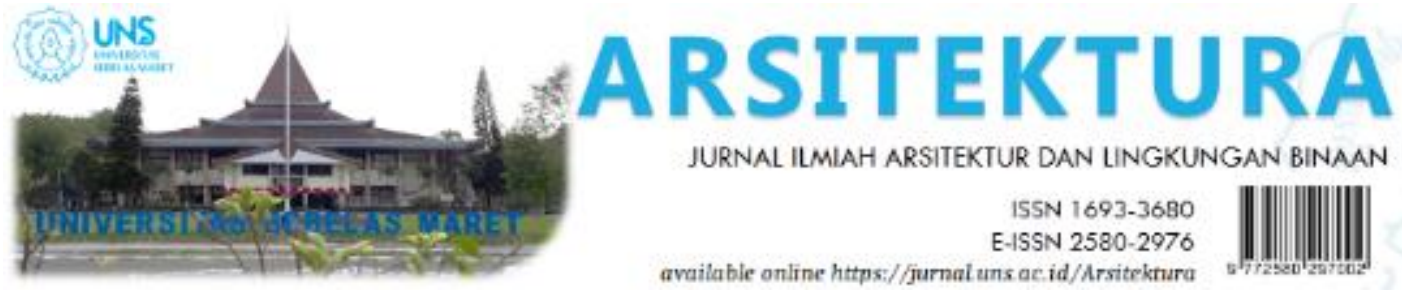

Volume 18 Issue 1 April 2020, pages: 53-62

\title{
Pengaruh Perubahan Fungsi Terhadap Tipologi Arsitektur Fasad Bangunan di Kampung Wisata Prawirotaman
}

\section{The Function Changes Impact to Facade Typology in Kampung Wisata Prawirotaman}

\author{
Aprodita Emma Yetti ${ }^{1 *}$, Tika Ainnunisa Fitria ${ }^{2}$, Indah Pujiyanti ${ }^{3}$ \\ Program Studi Arsitektur, Universitas Aisyiyah Yogyakarta ${ }^{1}$ \\ aproditaemma@unisayogya.ac.id \\ Program Studi Arsitektur, Universitas Aisyiyah Yogyakarta ${ }^{2}$ \\ Program Studi Arsitektur, Universitas Aisyiyah Yogyakarta ${ }^{3}$
}

DOI: https://doi.org/10.20961/arst.v18i1.35770

Received: November 22, 2019 Revised: March 21,2020 Accepted: March 24,2020 Available online:April 30, 2020

\begin{abstract}
The final results of this study describe the impact of changes in building functions on the facade typology in Kampung Prawirotaman. These results can be used for reference and consideration in the character and visual development of Kampung Prawirotaman. Kampung Prawirotaman is one of the tourism destination in Yogyakarta. Through a long history, Kampung Prawirotaman which is known as a batik village has been transformed into a tourism village. This area is supported by infrastructure and strategic locations. This area is close to the city center and the other tourist destinantions. Kampung Prawirotaman had an architectural heritage that form of the visual characters from the adaptation of traditional and "indis" architecture. Now, the community develop the tourism facilities as independently and spontaneously in this area. The tourism facilities has resulted in changes the various building facade elements in Kampung Prawiotaman. The research used descriptive qualitative method with architectural typology approach.
\end{abstract}

Keywords: tourism village, architecture, typology, façade, transform

\section{PENDAHULUAN}

Kampung Prawirotaman merupakan hunian bagi prajurit Kraton Kasultanan Yogyakarta di abad 19 sebagai wujud perhatian dari Sultan atas keterlibatan prajurit melawan penjajah. Keturunan prajurit Prawirotomo dikenal sebagai pengusaha batik cap dan kain tenun ATBM (Alat Tenun Bukan Mesin) yang akhirnya membuat Prawirotaman dikenal sebagai Kampung Batik hingga tahun 1970. Sekitar tahun 1970, usaha batik masyarakat meredup yang disebabkan menurunnya permintaan pasar dan tergerus importir dari negara lain. Seiring berkembangnya industri pariwisata di Yogyakarta, roda perekonomian masyarakat di Kampung Prawirotaman perlahan beralih ke industri pariwisata. Letak Kampung Prawirotaman yang strategis menjanjikan industri pariwisata berkembang.

Saat ini, Kampung Prawirotaman bertransformasi menjadi salah satu Kampung Wisata yang mendukung industri pariwisata 
Yogyakarta. Hal tersebut diperkuat dengan Peraturan Daerah Kota Yogyakarta tentang kebijakan pengembangan Kampung Wisata dan Prawirotaman termasuk didalamnya. Peninggalan arsitektur saat masa kejayaan Kampung Batik Prawirotaman menjadi warisan arsitektur yang dikelola masyarakat lokal untuk mendukung perekonomian masyarakat. Karakter visual arsitektur dapat dilihat dengan adanya beberapa bangunan lama yang identik dengan hasil adopsi konsep arsitektur Indis, dan bangunan-bangunan tradisional.

Keanekaragaman fasad yang dihasilkan dari perubahan era, fungsi, dan kondisi lingkungan dapat menjadikan kawasan ini memiliki kekhasan, identitas dan citra kawasan di masa depan. Uraian latar belakang dan permasalahan dari penelitian ini mengerucut pada hasil penelitian yang mampu menjelaskan wujud tipologi fasad bangunan di Kampung Prawirotaman sehingga dapat mengetahui karakteristik fasad arsitektur dari kawasan tersebut.

Beberapa literatur mendasari penelitian ini yang diharapkan dapat mendukung kajian mendalam untuk menghasilkan hasil penelitian yang akurat. Febriana (2012) dalam Mulyandari (2014) mendefinisikan tipologi sebagai klasifikasi dan mengkarakteristik secara umum dari fisik bangunan maupun perkotaan. Merujuk dari tinjauan teori, Keling (2016) menyimpulkan tipologi arsitektur memiliki keterkaitan dengan penelusuran elemen-elemen yang membentuk arsitektural. Elemen arsitektur tersebut dapat digunakan untuk mengidentifikasi tipologi dari suatu bangunan dengan mengklasifikasi kesamaan bentuk, struktur, dan karakter dari bangunan. Dalam penelitian ini, elemen arsitektur yang akan diidentifikasi adalah fasad bangunan. Fasad dideskripsikan oleh Utami et al (2013) sebagai unsur yang melekat dan menjadi bagian terpenting dari karya arsitektur, elemen fasad memberi gambaran tentang fungsi bangunan, penanda sejarah peradaban terkait kondisi sosial budaya, kondisi spiritual, ekonomi dan politik di masa tertentu. Hasil penelitian ini diharapkan dapat menjadi bahan acuan dan pertimbangan dalam pengembangan kawasan Kampung Wisata Prawirotaman yang dapat mendukung terwujudnya citra kawasan yang memiliki karakter.

Berdasarkan dari hipotesis awal bahwa karakteristik bangunan di Prawirotaman mengadopsi ciri khas arsitektur Indis, beberapa ciri khas dari arsitektur lokal yaitu arsitktur jawa dan modern, maka penulis merujuk literatur arsitektur Indis, arsitektur jawa dan arsitektur modern untuk dikaji. Arsitektur indis dipaparkan oleh Prastiwi, Saraswati, Witasari (2019) merupakan bangunan yang digunakan sebagai tempat tinggal pejabat pemerintah Hindia Belanda yang memiliki perpaduan dari ciri masing-masing bentuk bangunan Belanda dan rumah tradisional Indonesia. Ciri-ciri arsitektur Indis dijelaskan Handinoto (2012) dalam Purnomo, Waani, dan Wuisang (2017) dengan bangunan yang memiliki bentuk denah simetris, memiliki central room yang terdiri dari kamar tidur utama dan kamar mandi dimana kamar tidur memiliki akses langsung dengan teras. Bangunan indis biasanya memiliki teras yang cukup besar dengan elemen kolom bangunan yang bergaya Yunani. Handinoto (2006) dalam Purnomo et all (2017) juga menjelaskan karakter konstruksi atap yang digunakan adalah atap perisai dengan penutup genting, sedangkan bahan bangunan utama adaya batu bata secara menyeluruh baik struktur maupun selubung bangunan. Bangunan indis juga menggunakan kayu untuk kusen, pintu dan jendela.

Tipologi arsitektur jawa diklasifikasikan oleh Hamzuri (1985) dalam Roosandriantini, Santoso, Ambarwati (2019) dengan klasifikasi karakter atap dan pembagian ruang. Bentuk atap menyimbolkan golongan sosial seperti tajug untuk masjid, joglo untuk ningrat, limasan masyarakat menengah, atap kampung dan panggang pe untuk masyarakat biasa. Beberapa bangunan yang dijumpai di penggal jalan kampung Prawirotaman memperlihatkan dominasi arsitektur jawa yang menggunakan atap limasan. Roosandriantini, et all (2019) menjelaskan rumah limasan pada arsitektur jawa adalah rumah yang memiliki denah persegi panjang yang biasanya terdiri dari 4 atap dan menggunakan genteng tanah liat.

Rachman, Ashadi, dan Hakim (2018) mendeskripsikan arsitektur modern sebagai 
perkembangan arsitektur yang menekankan "ruang" adalah objek utama dimana merupakan gagasan-gagasan atau pandangan hidup yang tertuang dalam desain. Hasil desain yang dihasilkan pada arsitektur modern mampu dipertanggung jawabkan secara ilmiah.

\section{METODE}

Penelitian ini menggunakan metode penelitian deskriptif kualitatif dengan pendekatan tipologi arsitektur. Lokasi penelitian berada di Kampung Prawirotaman, Sisi utara berbatasan dengan Kampung Brontokusuman, sisi barat berbatasan dengan jalan Parangtritis, sisi timur dengan jalan Sisingamangaraja, dan sisi selatan berbatasan dengan kampung Prawirotaman 2.

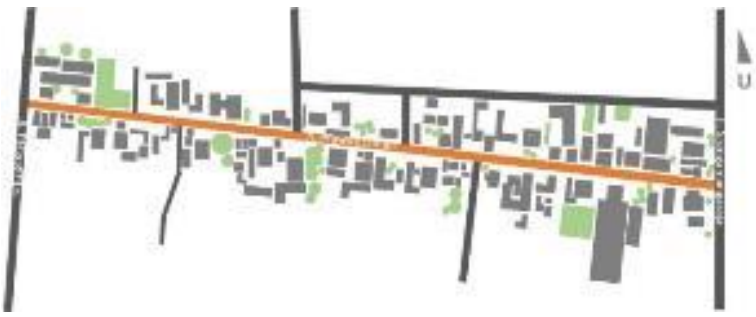

Gambar 1. Penggal Jalan Prawirotaman.

Pengumpulan data dilakukan dengan cara observasi lapangan, wawancara responden, dan dokumentasi. Saat melakukan observasi lapangan, peneliti menentukan objek penelitian dipilih berdasarkan teknik purposive sampling, yaitu objek dipilih berdasarkan kriteria yang ditentukan. Pada penelitian ini, objek yang diambil adalah beberapa bangunan yang mengadopsi konsep arsitektur Indis, arsitektur jawa, dan arsitektur modern di Kampung Wisata Prawirotaman. Lebih rinci pemilihan sampel juga diambil dari beberapa kategori bangunan yaitu :

1)

angunan yang tidak mengalami perubahan fungsi dan fasad,

2)

angunan yang mengalami perubahan fungsi dan ada perubahan fasad,

3)

angunan yang mengalami perubahan fungsi namun tidak mengalami perubahan fasad.
4)

angunan yang tidak mengalami perubahan fungsi namun terdapat perubahan fasad.

Sample juga dipilih berdasar keadaan fisik bangunan yang layak dan dapat diobservasi. Total sampling yang digunakan adalah 14 bangunan di ruas jalan Prawirotaman.

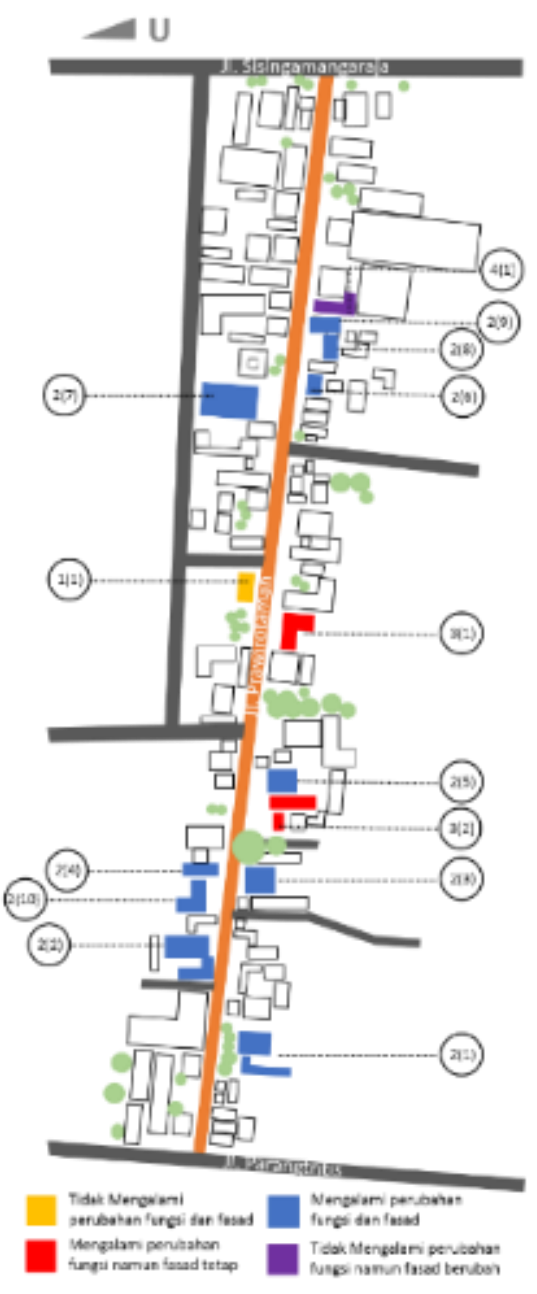

Gambar 2. Tebaran Sample.

Bangunan yang tidak mengalami perubahan fungsi dan fasad :

1(1). Balai Pertemuan (Rrsitektur Modern).

Bangunan yang mengalami perubahan fungsi dan fasad :

2(1). Wisma Gajah (adæmtasi arsitektur indis) 2(2). Hotel Borobudur (adaptasi arsitektur indis dan tradisional)

2(3). Hotel Putra Jaya (adaptasi arsitektur indis)

2(4). Annas Tour and Travel (adaptasi arsitektur indis). 
2(5). Arkadia communal space (adaptasi arsitektur indis).

2(6). Hotel Parikesit (adaptasi arsitektur indis). 2(7). Hotel Perwita Sari (Arsitektur Modern).

2(8). Hotel Prayogo (adaptasi arsitektur indis).

2(9). Hotel Prayogo III (adaptasi arsitektur indis).

2(10). Tropis Homestay (Arsitektur Modern) Bangunan yang mengalami perubahan fungsi namun tidak mengalami perubahan fasad :

3(1). Hotel Sumaryo (adaptasi arsitektur indis).

3(2) Hotel Prambanan (adaptasi arsitektur indis).

Bangunan yang tidak mengalami perubahan fungsi namun terdapat perubahan fasad :

4(1). Hunian warga (adaptasi arsitektur indis).

Metode ini menyajikan hasil penelitian dari dialog data dan temuan untuk memahami fenomena maupun persepsi yang ada. Hasil penelitian disajikan secara deskriptif dengan paparan yang runtun agar mudah dipahami.

\section{HASIL DAN PEMBAHASAN}

Merunut sejarah, penggal jalan Kampung Wisata Prawirotaman dulunya merupakan hunian sekaligus tempat usaha batik para trah prajurit Prawirotomo yang merupakan pengusaha batik. Seiring pergeseran fungsi kawasan, saat ini Kampung Prawirotaman didominasi oleh hunian masyarakat lokal. Berdasarkan hasil observasi, beberapa diantara hunian tersebut beralih fungsi maupun berubah wujud fasad untuk mewadahi fasilitas penunjang pariwisata seperti penginapan, café, restoran, pusat oleh-oleh, dan lainnya. Perubahan tersebut berpengaruh terhadap visual kawasan Kampung Prawirotaman. Objek Penelitian yang dipilih merupakan beberapa objek dengan temuan bangunan berubah fungsi, bangunan mengalami penambahan fungsi, dan bangunan yang tetap dalam fungsi aslinya. Diharapkan luaran dari setiap kasus menghasilkan simpulan tipologi fasad di Kampung Kauman. Komponen dari fasad bangunan yang dikaji terdiri dari elemen atap, badan bangunan (pintu, jendela, ornamen) dan kaki bangunan.

a. Analisis Bentuk Atap

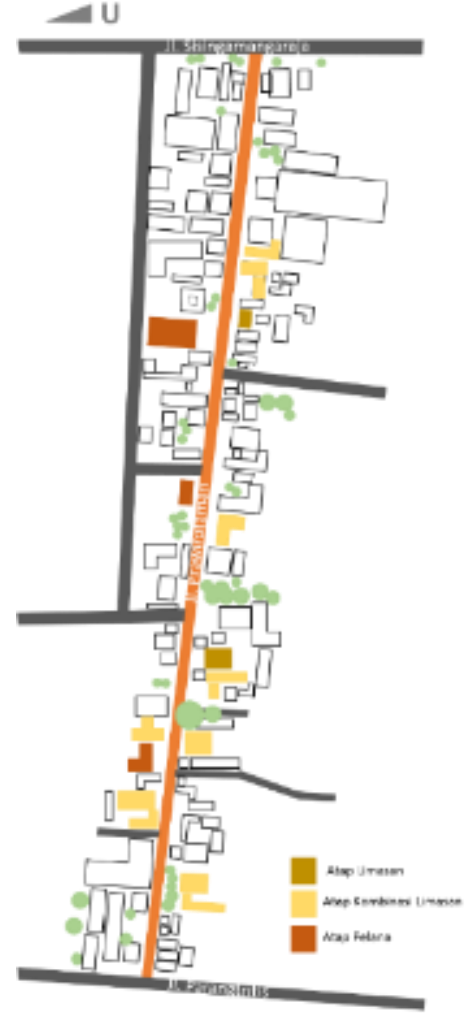

Gambar 3. Tebaran Jenis Atap

Hasil pengamatan dan analisis dari 14 objek pengamatan, menunjukan adanya 3 jenis atap yang dominan di Penggal jalan Prawirotaman.

- Tipe atap Limasan

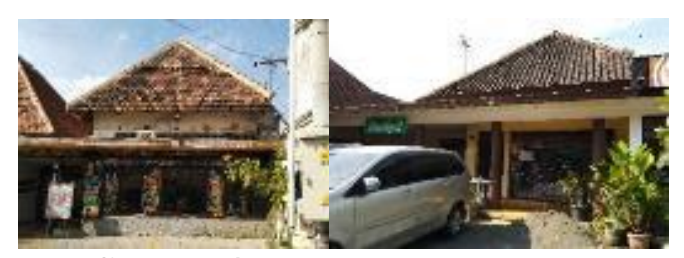

Gambar 4. Tipe Atap Limasan

Bangunan 2(5) dan 2(6) menggunakan tipe limasan pada atap dengan mempertahankan material genting tanah liat sebagai penutup atap. 


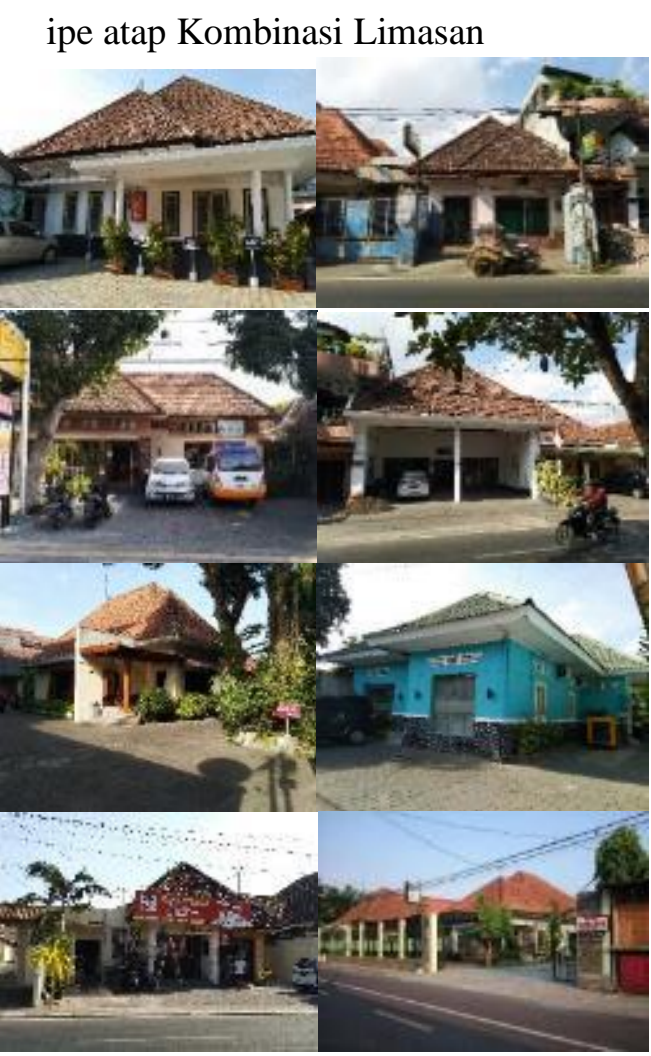

Gambar 5. Tipe Atap Kombinasi Limasan

Bangunan 2(1), 2(2), 2(4), 2(8), 2(9), $3(2), \quad 4(1)$ menggunakan tipe atap kombinasi limasan yang menggunakan limasan utama dengan tambahan limasan kecil, ketujuh bangunan tersebut menggunakan dan mempertahankan penutup atap dengan material tanah liat tradisional. Sedangkan bangunan 2(3) juga menggunakan atap kombinasi limasan, namun bahan penutup atap diganti menggunakan material metal ringan.

ipe Atap Pelana

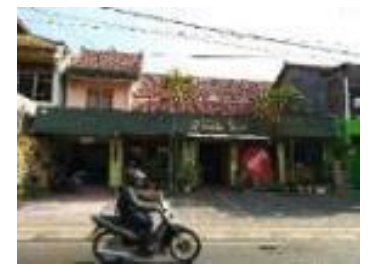

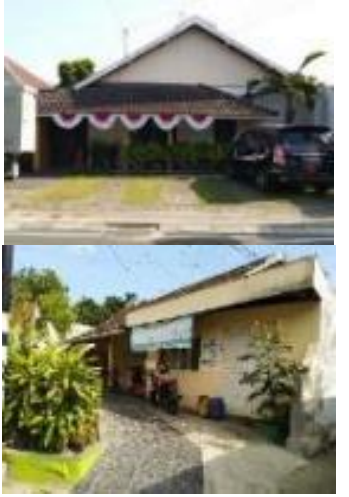

Gambar 6. Tipe Atap Pelana

Bangunan 1(1) dan 2(7) menggunakan tipe atap pelana dengan material penutup atap genteng tanah liat, sedangkan bangunan 2(10) menggunakan penutup atap sirip. Atap pelana merupakan bentuk atap yang memiliki bentuk bumbungan seperti pelana. Jenis atap ini relative aman, sederhana, dan mudah diterapkan pada bangunan. Jenis atap ini sering dijumpai di karakter bangunan arsitektur modern.

Jenis atap yang dominan digunakan di penggalan jalan Kampung Wisata Prawirotaman adalah jenis atap limasan dan pelana. Atap jenis ini merupakan bentuk atap konvensional yang kerap digunakan di Indonesia sebagai respon bangunan terhadap iklim tropis yang menggunakan kemiringan atap kisaran $45^{\circ}$ hingga $60^{\circ}$. Dengan adanya perubahan fungsi kawasan, dapat diidentifikasi tidak ada bangunan yang mengalami perubahan bentuk atap di Kampung Prawirotaman.

\section{b. Analisis Bentuk Bukaan}

Klasifikasi bukaan bangunan terdiri dari bukaan ventilasi atau lubang udara, jendela, dan pintu. Đari hasil pengamatan, berikut paparan tipologi berdasarkan masing-masing bukaan : 
- Ventilasi atau lubang udara

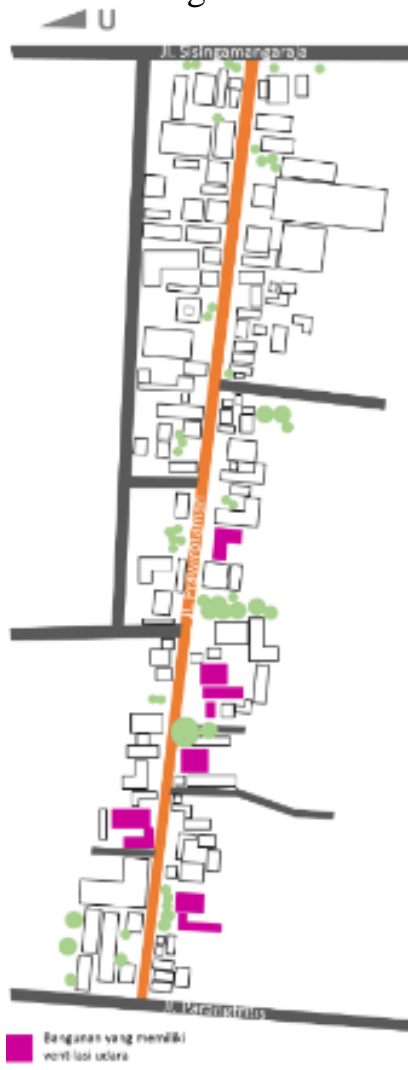

Gambar 7. Tebaran Bangunan dengan ventilasi udara

Dari 14 sample yang digunakan, tidak semua bangunan memiliki ventilasi atau lubang udara. Beberapa bangunan yang teridentifikasi menggunakan ventilasi dan lubang udara adalah bangunan-bangunan yang menggunakan adaptasi arsitektur indis dan mempertahankan elemen ventilasi atau lubang udara tersebut pada bangunan, seperti bangunan 2(1), 2(2), 2(3), 2(5), 3(1), dan 3(2).

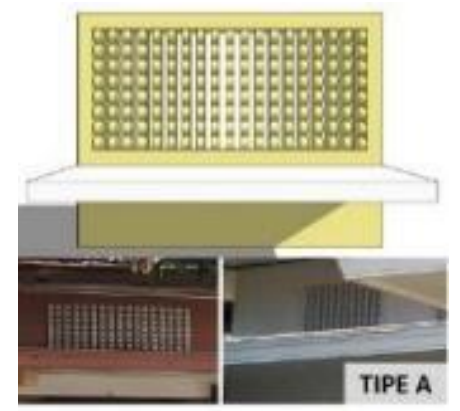

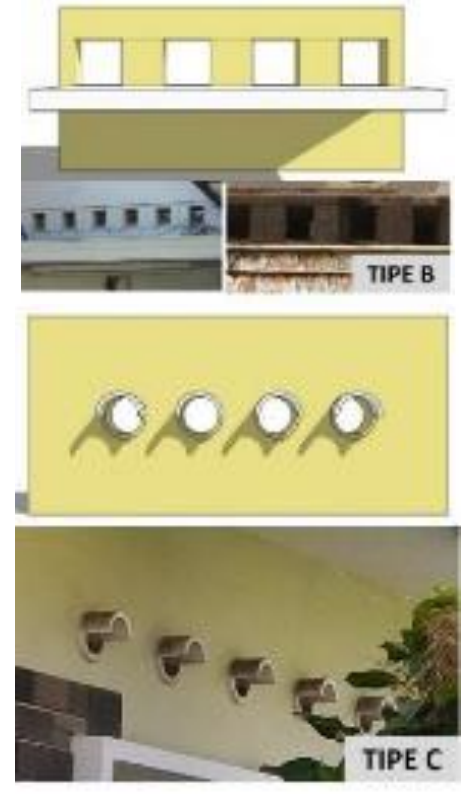

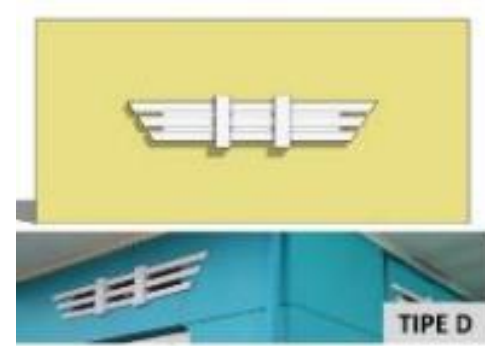

Gambar 8. Tipe Ventilasi

Terdapat 4 bentuk ventilasi dengan ukuran sedang. Hasil pengamatan memperlihatkan bentuk ventilasi yang dipertahankan mengadopsi ventilasi arsitektur indis. Bentuk ventilasi terdiri dari bentuk bouvenlicth (tipe A), persegi (tipe B) dan lingkar utuh (tipe C) dengan elemen garis dan bidang untuk mempertegas bentuk. Beberapa ventilasi lain seperti tipe $\mathrm{D}$ memiliki bentuk persegi dengan permainan garis horizontal. Dari keempat tipe ventilasi, penulis menyimpulkan bentuk ventilasi yang dipertahankan pada bangunan memberi tampilan fasad yang tetap memiliki kesan arsitektur indis. Sehingga, tampilan tersebut tetap mempertegas estetika bangunan dan memberi daya tarik fasad. 
- Jendela

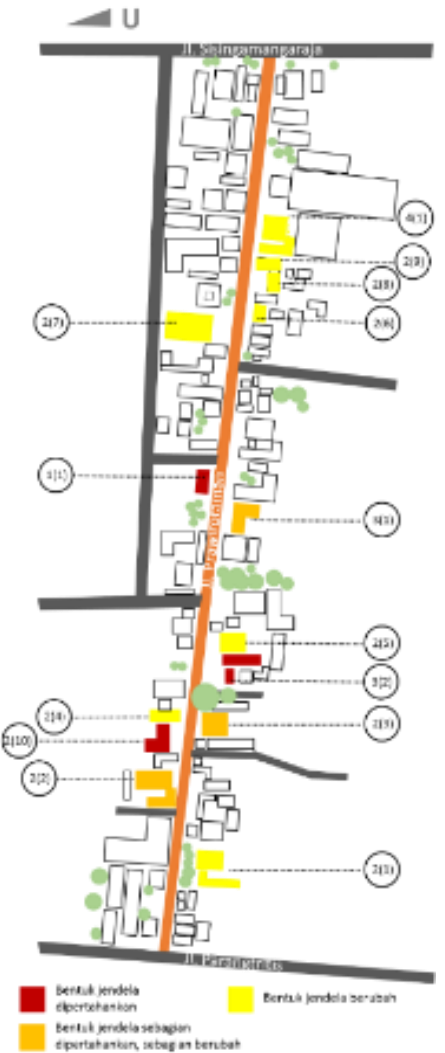

Gambar 9. Tebaran bangunan dengan bentuk jendela dipertahankan, diubah sebagian dan diubah keseluruhan.

Jendela sebagai bagian bukaan bangunan menjadi elemen pembentuk dan mempertegas fasad serta visual arsitektur bangunan. Dari 14 sample terdapat :

1. 3 bangunan yang telah berubah fungsi namun tetap mempertahankan bentuk asli jendela,

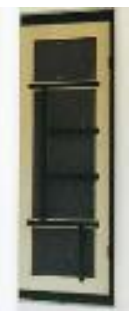

Gambar 10. Bentuk jendela asli dengan adopsi arsitektur indis

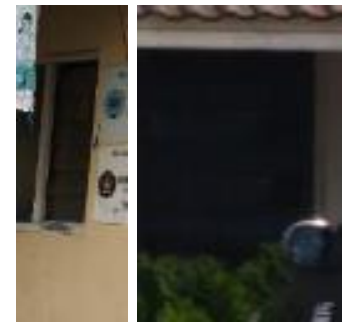

Gambar 11. Bentuk jendela asli dengan adopsi arsitektur modern

Jenis jendela pada bangunan yang dipertahankan bentuk aslinya di Kampung Prawirotama adalah jendela hidup yang menjadi alur sirkulasi udara dan cahaya di dan ke dalam ruangan. Material dominan yang digunakan adalah kayu dengan finishing cat. Untuk bangunan yang mengadopsi arsitektur indis, jendela rata-rata menggunakan ornamen dan bentuk simetris. Sedangkan bangunan dengan arsitektur modern menggunakan material kaca tanpa ornamen.

2. 3 bangunan yang berubah fungsi dengan sebagian jendela dipertahankan dan sebagian lagi diubah,

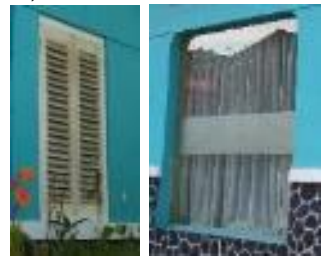

Gambar 12. Bentuk jendela di bangunan 2(3) - Hotel Putra Jaya

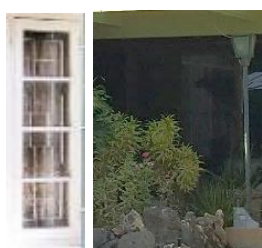

Gambar 13. Bentuk jendela di bangunan 3(1) - Hotel Sumaryo 

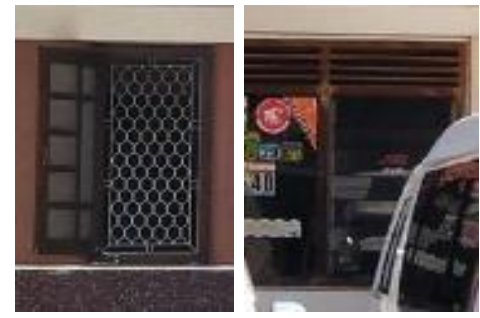

Gambar 14. Bentuk jendela di bangunan 2(2) - Hotel Borobudur

3. 7 bangunan yang berubah fungsi dengan bentuk jendela yang juga berubah.

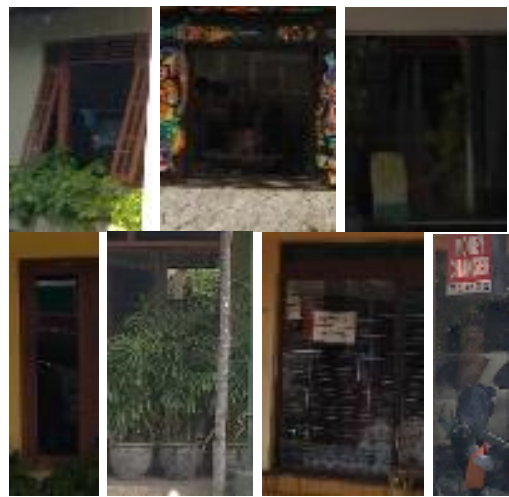

Gambar 15. Bentuk jendela di bangunan Berubah fungsi dan bentuk

4. 1 bangunan dengan fungsi tetap namun berubah bentuk jendela.

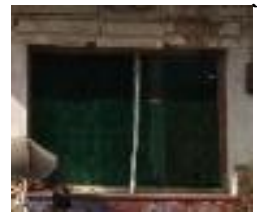

Gambar 16. Bentuk jendela di bangunan yang tidak berubah fungsi namun fasad berubah

Dari data yang dikaji, bentuk jendela di penggal jalan Kampung Prawirotaman yaitu bentuk persegi dengan komposisi simetris. Dari pengamatan beberapa sampling, model jendela yang ada terdiri dari 2 tipe yaitu jendela dengan daun jendela tunggal maupun daun jendela rangkap. Dominasi jendela dilengkapi dengan tralis bermotif sebagai aspek keamanan dan estetika. Beberapa rumah juga menggunakan jendela krepyak (jalusi) dan kaca sebagai wujud adaptasi iklim. Material didominasi dengan kayu massif dengan finishing cat. Fungsi ruang mempengaruhi dimensi jendela.

- Pintu
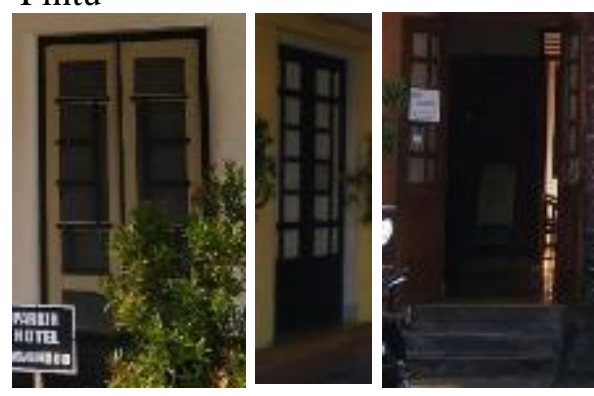

Gambar 17. Tipe Pintu

Pintu sebagai media penghubung ruang dan aktifitas memberi kontribusi tipologi dan ciri khas arsitektur fasad di Kampung Prawirotaman. Dari sampling pengamatan, pintu utama di bangunan yang digunakan adalah pintu ganda dan bukaan ayun dengan material kayu solid lapis cat dan tambahan ornamen kaca es dengan dimensi pintu yang cukup besar dengan tinggi \pm 1.80 dan lebar \pm 0.60 setiap daun pintu. Berdasarkan hasil pengamatan sampling, bentuk pintu di Kampung Prawirotaman menggunakan komposisi bentuk simetri dengan susunan dasar persegi.

c. Analisis Kaki Bangunan

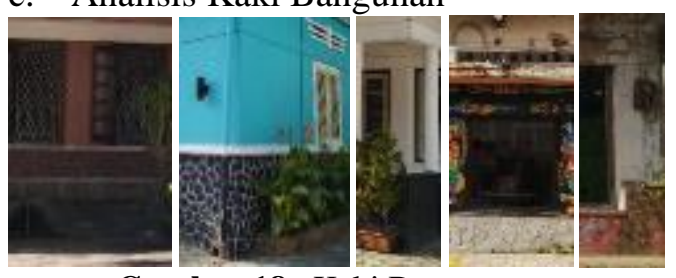

Gambar 18. Kaki Bangunan

Material lantai bangunan didominasi dengan teraso polos, namun beberapa sudah berubah menjadi lantai keramik menyesuaikan dengan kebutuhan dan fungsi bangunan. Rata-rata ketinggian dari muka tanah antara 0.15-0.30. dibagian kaki bangunan terdapat elemen batu kali dengan ketinggian sekitar 1.00 meter dari permukaan tanah dengan ketebalan sekitar 0.10 . 
Dialog data dari 14 sampling bangunan di ruas jalan Kawasan Prawirotaman menunjukkan adanya perubahan fungsi dan wujud arsitektur, bangunan dengan perubahan fungsi dan sebagian wujud arsitektur, serta bangunan yang tetap bertahan dengan fungsi dan wujud arsitektur.

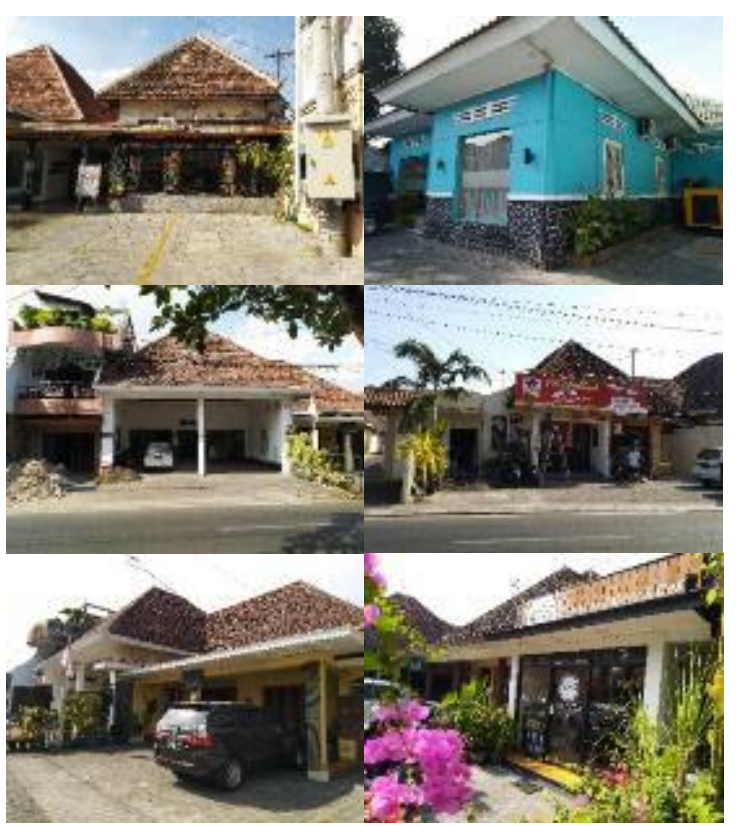

Gambar 19. Perubahan Elemen Fasad

Perubahan yang teridentifikasi yaitu :

- Perubahan elemen bukaan pintu dan jendela menjadi jendela mati sebagai respon kebutuhan fungsi.

- Pengurangan fasad bangunan sebagian sebagai respon kebutuhan kantong parkir untuk fungsi penginapan.

- Tertutupnya fasad bangunan asli dengan reklame atau iklan atau penambahan material non permanen untuk memperkuat karakter dari fungsi bangunan baru.

- Penambahan elemen dinding di fasad bangunan sebagai respon kebutuhan ruang café.

\section{KESIMPILAN}

Tipologi fasad arsitektur di Kampung Prawirotaman memperlihatkan bahwa arsitektur kampung Prawirotaman mengadopsi arsitektur indis, karena tidak ditemukan hasil dokumentasi fisik maupun wawancara yang memperlihatkan bahwa arsitektur Kampung Prawirotaman merupakan peninggalan kolonial. Merunut sejarah, Hunian arsitektur indis seyogyanya merupakan hunian bagi pekerja pemerintah Belanda saat menjajah Indonesia, sedangkan Kampung Prawirotaman berdasarkan observasi di lapangan merupakan kampung asli pribumi. Dengan mengadopsi arsitektur indis, arsitektur di Kampung ini tetap mempertahankan karakter dan unsul kelokalan untuk merespon iklim. Hal tersebut dapat dilihat dengan ukuran atap dan bukaan serta penggunaan material bangunan sebagai respon iklim. Perubahan dominan dari wujud arsitektur fasad di Kampung Prawirotaman terlihat dari perubahan wujud bukaan seperti pintu dan jendela yang menyesuaikan kebutuhan dari fungsi tambahan bangunan saat ini.

Perubahan fungsi kawasan sebagai Kampung Batik menjadi Kampung wisata memberi dampak adanya perubahan fungsi bangunan yang akhirnya memberi dampak kepada perubahan fasad bangunan. beberapa diantara seperti (1) perubahan secara total fasad bangunan, (2) perubahan elemen fasad seperti bentuk bukaan, (3) tertutupnya fasad dengan papan reklame dan iklan. Perubahanperubahan tersebut berpengaruh kepada melemahnya karakter visual arsitektur dari Kampung Prawirotaman. Hendaknya perubahan fungsi hunian dan elemen bangunan disertai dengan pertimbagan karakter visual suatu kawasan agar ciri khas dari suatu kawasan tersebut tetap terjaga dan makin kuat.

\section{UCAPAN TERIMAKASIH}

Penelitian ini dilakukan dengan dukungan pendanaan dari Kemenristekdikti atas dana Penelitian Dosen Pemula pendanaan tahun 2019, sehingga penelitian ini dapat berjalan dengan lancar.

Penulis juga mengucapkan terima kasih kepada penyelenggara dan reviewer International Conference of Architecture Dept. 17 Agustus 1945 Semarang atas kesempatannya bagi penulis untuk mendapat arahan dan masukan sehingga penelitian ini dapat diselesaikan dengan lebih baik. 


\section{REFERENSI}

Peraturan Walikota Yogyakarta Nomor 115 Tahun 2016 Tentang Penyelenggaraan Kampung Wisata.

Fajari, Safinta Rhosa. Atiek Suprapti, dan Bambang Supriyadi. (2014). Pengaruh Aktivitas Penunjang Wisata Terhadap Perubahan Tata Ruang Desa dan Tata Ruang Rumah Tinggal. Studi Kasus : Desa Wisata Bejiharjo, Yogyakarta. Jurnal Tesa Arsitektur Vol. XII no. 2, Desember 2016, hal. 114-128.

Harimu, Threesje A, Antariksa dan Lisa Dwi Wulandari (2012). Tipologi Wajah Bangunan Arsitektur Kolonial Belanda di Kawasan Pabrik Gula Semboro Jember. Arskon, Jurnal Arsitektur \& Konstruksi Vol. 1, No. 1, April 2012, hal 66-79.

Keling, Gendro (2016). Tipologi Bangunan Kolonial Belanda di Singaraja. Forum Arkeologi Volume 29, Nomor 2, Agustus 2016, hal 65-80.

Mulyandari, Hestin (2014). Tipologi Perubahan Fungsi Lahan Bangunan di Perkotaan Studi Kasus Perkembangan Bangunan Komersial Penggal Jalan Monjali - Jalan Abu Bakar Ali Yogyakarta. Jurnal Teknik Sipil dan Perencanaan, Vol 16, No.2, hal 251-161.

Prastiwi, Resti Eka, Ufi Saraswati, dan Nina Witasari. (2019) Sejarah Perkembangan Arsitektur Bangunan Indis di Purworejo Tahun 1913-1942. Journal of Indonesian History 8(1)(2019), hal 88-95.

Purnomo, Hery, Judi O. Waani, dan Cynthia E.V.Wuisang. (2017) Gaya dan Karakter Visual Arsitektur Kolonial Belanda di Kawasan Benteng Oranje Ternate. Media Matrasain, Volume 14 No. 1, Maret 2017, hal 23-33.

Rachman, Delly, Ashadi, Luqmanul Hakim. (2018) Pencampuran Arsitektur Tradisional dan Modern Pada Perencanaan Taman Walisongo di Cirebon. Jurnal Arsitektur PURWARUPA Volume 02 No. 1 Maret 2019, hal 29-34.
Roosandriantini, Josephine, Angelina Novemita Santoso, Catherina Novita Ambarwati (2019) Tipologi Bentuk Atap pada Arsitektur Jawa. JA!UBL-Jurnal Arsitektur, Volume 09, No.2 hal 7-12.

Santoso, Iman dan Beni G. Wulandanu. (2011). Studi Pengamatan Tipologi Bangunan pada Kawasan Kauman Kota Malang. Jurnal Local Wisdom Volume : III , Nomor : 2, Juli 2011, hal 10-28.

Setyaningsih, Wiwik. Wiendu Nuryanti, Budi Prayitno dan Ahmad Sarwadi. (2015). Proses Perubahan Arsitektural Kawasan Bersejarah Kampung Wisata Kauman Surakarta. REGION Vol. 6 No.2, hal 6975.

Sugiyono. (2008). Metode Penelitian Kuantitatif dan Kualitatif. Alfabeta : Bandung.

Utami, Mario Wibowo, Abdul Jabbar Faruk. (2014). Kajian Bentuk dan Fasad Hotel Gino Feruci Bandung. Reka Karsa Jurnal Online Institut Teknologi Nasional Vol. 1 No. 4, Januari 2014.

Wulur, Fanny Alfrits, Veronica A. Kumurur \& Ivan R.B Kaunang (2015) Gaya Bangunan Arsitektur Kolonial Pada Bangunan Umum Bersejarah di Kota Manado. Sabua Vo.7, No 1, Maret 2015, hal 371-382. 